\title{
An Overview of Biomaterials in Periodontology and Implant Dentistry
}

\author{
Young-Dan Cho, ${ }^{1}$ Yang-Jo Seol, ${ }^{1}$ Yong-Moo Lee, ${ }^{1}$ In-Chul Rhyu, \\ Hyun-Mo Ryoo, ${ }^{2}$ and Young $\mathrm{Ku}^{1}$ \\ ${ }^{1}$ Department of Periodontology, School of Dentistry and Dental Research Institute, BK21 Program, \\ Seoul National University, Seoul, Republic of Korea \\ ${ }^{2}$ Department of Molecular Genetics, School of Dentistry and Dental Research Institute, BK21 Program, \\ Seoul National University, Seoul, Republic of Korea
}

Correspondence should be addressed to Young Ku; guy@snu.ac.kr

Received 6 September 2016; Revised 6 December 2016; Accepted 18 December 2016; Published 9 January 2017

Academic Editor: Luiz F. de Moura

Copyright (C) 2017 Young-Dan Cho et al. This is an open access article distributed under the Creative Commons Attribution License, which permits unrestricted use, distribution, and reproduction in any medium, provided the original work is properly cited.

\begin{abstract}
Material is a crucial factor for the restoration of the tooth or periodontal structure in dentistry. Various biomaterials have been developed and clinically applied for improved periodontal tissue regeneration and osseointegration, especially in periodontology and dental implantology. Furthermore, the biomimetic approach has been the subject of active research in recent years. In this review, the most widely studied biomaterials (bone graft material, barrier membrane, and growth or differentiation factors) and biomimetic approaches to obtain optimal tissue regeneration by making the environment almost similar to that of the extracellular matrix are discussed and specifically highlighted.
\end{abstract}

\section{Introduction}

Periodontitis, a common periodontal disease, is an inflammatory disease that damages soft tissue and induces periodontium destruction [1]. Gingival recession or alveolar bone resorption, which is caused by periodontal disease or trauma, has been a challenge for both dental clinicians and researchers. Over the years, many studies reported the success of periodontal regeneration using various strategies, including root planning, gingival curettage, and open flap debridement procedure [2]. However, these therapeutic approaches without the use of supportive materials present limitations to induce genuine tissue regeneration in the compromised sites. With the progress in the development of biomaterials for tissue engineering, several methods of regenerative periodontal therapy, including the use of bone graft, growth factors, barrier membrane, and combined procedures, have been investigated [3]. Guided tissue regeneration (GTR) [4] or guided bone regeneration (GBR) [5] was introduced to regenerate periodontal tissue in the defect site and has been performed with various biomaterials.

\section{Biomaterials in Periodontology}

2.1. Tissue Engineering in Periodontology. Tissue engineering is an interdisciplinary field, which advanced from the development of biomaterials to restore or maintain the function of impaired tissue or organ. Langer and Vacanti proposed tissue engineering as a possible technique for the regeneration of lost tissues [6]. Tissue engineering approaches in periodontology mainly focus on oral soft tissue and alveolar bone regeneration, and they are combined with three key elements to enhance tissue regeneration: progenitor cells, scaffold or supporting matrix, and signaling molecules [7].

2.1.1. Oral Soft Tissue Wound Healing: Repair versus Regeneration. Soft tissue healing around the teeth, dental implant, and edentulous ridge follows a pattern similar to that of skin wound healing, including hemostasis, inflammation, cell proliferation, and maturation/matrix remodeling $[8,9]$. The common outcome of wound healing is soft tissue repair by formation of a long junctional epithelium between the root surface and gingival connective tissue [10]. However, wound healing via regeneration is characterized by de novo 
TABLE 1: Types of barrier membrane in periodontal regeneration.

\begin{tabular}{lll}
\hline Type & Material & Brand \\
\hline & Natural membrane & \\
& A cellular dermal allograft & Alloderm \\
& Oxidized cellulose mesh & Surgicel \\
Resorbable & Type I collagen membrane & Biogide, Biomend, Ossix plus, Biosorb \\
& Synthetic membrane & \\
& Polylactic acid derivatives & Epiguide, Atrisorb, Osmed, Guidor \\
& Combination of polylactic and polyglycolic acid derivatives & Ethisorb, Resolute, Vicryl mesh \\
\hline & Cellulose acetate filter & Millipore paper filter \\
& Rubber dam & Rubber filter \\
& Expanded polytetrafluoroethylene (e-PTFE) & Gore Tex \\
& Dense polytetrafluoroethylene (d-PTFE) & Cytoplast \\
& Titanium mesh & Cytoflex \\
Ethylene cellulose & BenaCel \\
\hline
\end{tabular}

formation of cementum and periodontal ligament (PDL) with a short epithelial attachment establishing the gingival unit. For tissue regeneration, various technologies using barrier membrane to obtain selective cell colonization, growth factor to alter the microenvironment increasing soft tissue healing, and scaffold to improve the ingrowth of cells and maintain the grafted space have been developed [10].

(1) Barrier Membranes. The application of membrane originated from the principle of GTR, which is a technique to place a barrier membrane between the surgical flap and root surface, allowing selective cell recruitment and formation of new cementum, PDL, and bone $[11,12]$. The membranes are derived from a natural or synthetic origin and are divided in two types, resorbable versus nonresorbable material (Table 1). The first developed membrane was nonresorbable. However, the additional surgical procedure to remove the membrane led to the development of resorbable membranes. Resorbable membranes are mainly animal derived or synthetic polymers. They are easy to use, without additional surgery, as they are gradually degraded. Compared to nonresorbable membranes, resorbable membranes allow for lesser exposure that reduces the risk to bacterial infection in the grafted site. However, it is difficult to support the grafted materials for a long time. On the other hand, nonresorbable membranes present the advantage of maintaining the space [13-15]. Therefore, an appropriate selection suitable for the tissue defect is required to obtain good clinical outcome.

\section{(2) Growth or Differentiation Factors}

(i) Enamel matrix derivative (EMD, for example, Emdogain ${ }^{\circledR}$, Straumann, Basel, Switzerland) is an extract of enamel matrix and contains amelogenins, which are used to biomimetically stimulate the soft and hard tissues surrounding the teeth to regenerate following tissue destruction $[16,17]$.

(ii) Platelet rich plasma (PRP) is a platelet concentrate, which accelerates soft and hard tissue healing. The main substance is platelet-derived growth factor
TABLE 2: Types of bone graft materials in periodontal regeneration.

\begin{tabular}{ll}
\hline Type & Material \\
\hline Autograft & $\begin{array}{l}\text { Extraoral } \\
\text { Iliac Crest, Tibia, Fibula, Ribs } \\
\text { Intraoral } \\
\text { Chin, Exostosis, Ramus, Tuberosity }\end{array}$ \\
\hline Allograft & $\begin{array}{l}\text { Mineralized (FDBA) and demineralized } \\
\text { freeze-dried bone allografts (DFDBA) }\end{array}$ \\
\hline Xenograft & Bovine derived, porcine derived, equine derived \\
\hline Alloplast & $\begin{array}{l}\text { Hydroxyapatite, calcium phosphate, } \beta \text {-TCP, } \\
\text { bioactive glass, synthetic glass }\end{array}$ \\
\hline
\end{tabular}

(PDGF), which is involved in wound healing by stimulating angiogenesis, granulation tissue formation, initial epithelial migration, and hemostasis [18]. GEM $21 S^{\circledR}$ (Osteohealth, Shirley, NY, USA) is a product available for clinical use. It consists of a concentrated solution of pure recombinant human PDGF-BB and an osteoconductive beta-tricalcium phosphate $(\beta$ TCP) as a scaffold.

(iii) Bone morphogenetic protein is an important cytokine for the development of bone and cartilage [19]. BMP2 and BMP-7 are osteoinductive BMPs, which stimulate osteoblast differentiation [20, 21]. Recombinant human BMP-2 (rhBMP-2) is available for orthopedic surgery or periodontal tissue regeneration [22].

(3) Bone Graft Material. Bone grafting is a technique for the replacement of missing bone with alternative materials. Bone graft materials are used as scaffold or filler to promote bone formation and wound healing. These materials are broadly divided into autograft, allograft, xenograft, and alloplast (Table 2), which act as a mineral reservoir to assist new bone formation $[23,24]$.

2.1.2. Bone Remodeling at a Glance [50]. Bone remodeling is a complex and highly coordinated process in which the old bone is continuously replaced by new tissue [51]. The 
remodeling cycle is composed of five consecutive phases: the activation phase, which involves the initiation of the bone remodeling signal; the resorption phase, during which osteoclasts digest the old bone; the reversal phase, which generates an osteogenic environment; the formation phase, a process by which new bone is produced; the termination phase, which informs the remodeling machinery to cease the remodeling cycle [52]. The bone remodeling process requires an intimate interaction between different cell types and is regulated by cellular and molecular mechanisms $[53,54]$.

2.2. Osseointegration around the Dental Implant. Osseointegration or osteointegration is defined as a direct connection between the living bone and the surface of the dental implant without insertion of nonbone tissue [55]. After the initial observation of osseointegration by Brånemark et al., the concept of osseointegration was defined at various levels, clinically [56], anatomically [57], structurally [58], and histologically [59]. The bone healing procedure around dental implants involves cellular and extracellular biological events, which occur at the bone-to-implant interface until the implant surface is finally covered by new bone formation [60]. This cascade of biological events is similar to those involved in bone healing, activating osteogenic processes regulated by various growth or differentiation factors [61]. Titanium (Ti) is a widely accepted dental implant material because of its biocompatibility and durability [62-64]. As osseointegration is involved in the bone to material interface, the surface characteristic is a major factor to accelerate osseointegration. Therefore, many studies focused on improving $\mathrm{Ti}$ surface conditions by incorporation of optimal surface roughness (e.g., machined [65], sandblasted [66], acid etched [67, 68], anodized [69, 70], and laser modifications $[71,72])$ and surface coating with osteoconductive compounds (e.g., hydroxyapatite [73] and calcium phosphate [74]) and biomolecules (BMP-2 [75]) to enhance osteointegration [76-80]. Osteoinductive biomolecules could elicit the differentiation of mesenchymal cells to osteoblasts [81]. These methods enable the induction of de novo bone formation, thereby accelerating bone formation. One attractive approach to bestow osteoinductivity is to mimic the native environmental structure of the extracellular matrix (ECM), that is, biomimetics, which garnered considerable interest in the field of dental implantology [82].

2.3. Biomimetics. Biomimetics is defined as the imitation of the models, systems, and elements of nature for the purpose of solving complex human problems [83, 84]. Biomaterials play an important role as scaffolds to maintain the space and synthetic ECM environment for tissue regeneration [85, 86]. The ECM is a $3 \mathrm{D}$ microenvironment composed of various proteins, fiber-forming proteins such as collagens, and elastic fiber and non-fiber-forming proteins such as proteoglycan (e.g., glycosaminoglycan), glycoprotein (e.g., fibronectin and integrin), and other soluble factors [87]. Cells residing in the ECM bind to the ECM via cell surface receptors, inducing the activation of cellular responses such as migration, proliferation, and differentiation $[88,89]$. Therefore, the components, biomechanics, and structures mimicking the
TABLE 3: ECM components and biomimetic applications.

\begin{tabular}{ll}
\hline Components & Publications \\
\hline Collagen (types I, III) & (1) Yang et al. (2004) [25] \\
& (2) Sachlos et al. (2006) [26] \\
& (3) Davidenko et al. (2012) \\
& [27] \\
& (4) Lee et al. (2013) [28] \\
\hline & (1) Correia et al. (2011) [29] \\
(2) Weyers and Linhardt \\
Proteoglycan (chondroitin sulfate, \\
hyaluronic acid) \\
(2013) [30] \\
(3) Lian et al. (2013) [31] \\
(4) Credi et al. (2014) [32] \\
\hline (1) Kim et al. (2011) [33] \\
Glycoprotein (fibronectin, integrin) Lee et al. (2014) [34] \\
(3) Cho et al. (2016) [35] \\
(4) Chang et al. (2016) [36] \\
\hline (1) Park et al. (2006) [37] \\
(2) Yeo et al. (2008) [38] \\
(3) Kundu et al. (2010) [39] \\
(4) Chen et al. (2012) [40] \\
(5) Wang et al. (2013) [41] \\
(6) Zhang et al. (2015) [42] \\
\hline (1) Shi et al. (2005) [43] \\
(2) Zhao et al. (2012) [44, 45] \\
(3) Algul et al. (2015) [46] \\
(4) Algul et al. (2016) [47] \\
\hline
\end{tabular}

ECM are highly important to induce an excellent biological effect of biomaterials.

\subsubsection{Current Technologies and Applications with a Biomimetic Approach}

\section{(1) ECM Proteins (Table 3)}

(1) Collagen: type I collagen is a structural framework molecule found in connective tissues that plays an important role in de novo bone formation [25].

(2) Fibronectin (FN): FN is a noncollagenous protein of the ECM that is mainly expressed in the early stage of osteogenesis [90, 91].

(2) Growth Factors with a Biomimetic Delivery System. Delivery of growth factors combined with biomimetic scaffolds such as micro- or nanoparticles and controlling their bioavailability are key points for an effective approach toward the improvement of tissue engineering [92]. Many studies highlighted the use of biomimetic materials forming ECMlike structures. The rationale for using biomimetic scaffolds is based on the consideration that the ECM is a natural scaffold, because the ECM provides proper physical, chemical, and biological cues for cellular response [93].

(3) Surface Modification of Dental Implant. Surface activation of dental implants with biomolecules has been investigated 
TABLE 4: Experimental surface alteration [48].

\begin{tabular}{ll}
\hline Experimental surface alteration & Publications \\
\hline & (1) Schliephake et al. (2002) \\
& (2) Rammelt et al. (2004) \\
& (3) Bernhardt et al. (2005) \\
& (4) Morra (2006) [49] \\
Collagen & (5) Reyes et al. (2007) \\
& (6) Stadlinger et al. (2008) \\
& (1) Schliephake et al. (2002) \\
& (2) Bernhardt et al. (2005) \\
& (3) Germanier et al. (2006) \\
& (4) Jung et al. (2007) \\
(5) Rammelt et al. (2007) & (6) Park et al. (2007) \\
RGD-including sequence & (7) Petrie et al. (2008) \\
(8) Stadlinger et al. (2008) \\
(1) Franke Stenport et al. (2003) \\
(2) Fuerst et al. (2003) \\
(3) De Ranieri et al. (2005) \\
(4) Anitua (2006) \\
(5) Becker et al. (2006) \\
(6) Park et al. (2006) \\
(7) Liu et al. (2007a, 2007b) \\
(8) Stadlinger et al. (2008) \\
(9) Wikesjö et al. (2008) \\
(10) Freilich et al. (2008) \\
Growth factors
\end{tabular}

to accelerate bone healing. Generally, a specific ECM protein is coated onto the dental implant surface, which stimulates cellular proliferation or differentiation [94]. ECM plays key roles in cell attachment, which is mediated by cell adhesion receptors such as integrin. Usually, integrin binds to a specific amino acid motif, "RGD," which mainly exists in type I collagen, fibronectin, osteopontin, and bone sialoprotein. Besides, ECM regulates cellular migration, proliferation, survival, and morphological change [95]. Type III collagen acts as a scaffold for cell migration, and ECM glycoproteins or proteoglycans bind to cytokines and growth factors [96]. Based on these data, implant surface modification by ECM component might improve the healing potential and function. Although various biomimetic approaches have been introduced (Table 4), they are still experimental. Mechanical or chemical methods (e.g., resorbable blast media, anodizing, and sandblasted large grit acid-etching) are widely used in the dental field due to problems with clinical application of biomimetic approaches such as surface coating efficiency, osteogenic potential in vivo, and inflammatory reaction [48].

\subsubsection{Research Trends in Biomimetic Materials}

(1) Three-Dimensional (3D) Bioprinting. 3D bioprinting is a technology developed to create the native 3D environment of the ECM in a confined space where cellular response is preserved within a printed structure. This technique would contribute to significant advances in the tissue engineering field. Compared to nonbiological printing, 3D bioprinting requires additional complexities such as biomaterials, type of cells, and growth or differentiation factors [97].

(2) 3D-Printed Bioresorbable Scaffolds for Periodontal Regeneration. As the reconstruction of complex tissues or organs such as the periodontium requires a well-fitted biomaterial at the defect site, 3D-printed templates with synthetic ECM environment might be promising tools for tissue engineering [98]. The efficacy of 3D-printed biomaterials was recently demonstrated preclinically $[99,100]$. However, there are many limitations to overcome for more personalized clinical applications with a proper structure and resorption rate of the materials [101, 102].

\section{Conclusions and Perspectives}

In this review, we highlighted the use of biomaterials in periodontology and implant dentistry. Although several studies highlighted the success of tissue engineering applications in periodontology and implant dentistry using various types of biomaterials such as bone materials, cell-occlusive barrier membrane, and growth or differentiation factors, it would be more important to understand the biological processes involved in tissue regeneration to mimic them. On that note, the biomimetic approach seems promising and enhances the biomaterial research with previous achievement in the tissue regeneration field. Although some progress has been observed in the reconstruction of periodontal tissue and alveolar bone defects over the past decade, further biomimetic studies are still needed to challenge the current problems for clinical application. The selected biomimetic approach involves the design of a biomaterial to which the hostbiological system could respond in a more favorable and effective manner, providing an exciting new era for the research and development of biomaterials.

\section{Competing Interests}

The authors declare that there are no competing interests regarding the publication of this paper.

\section{Acknowledgments}

This research was supported by a grant from the Korea Health Technology R\&D Project through the Korea Health Industry Development Institute (KHIDI, Seoul, Republic of Korea), funded by the Ministry of Health \& Welfare, Republic of Korea (HI14C2681).

\section{References}

[1] A. Savage, K. A. Eaton, D. R. Moles, and I. Needleman, "A systematic review of definitions of periodontitis and methods that have been used to identify this disease," Journal of Clinical Periodontology, vol. 36, no. 6, pp. 458-467, 2009. 
[2] L. J. Heitz-Mayfield, L. Trombelli, F. Heitz, I. Needleman, and D. Moles, "A systematic review of the effect of surgical debridement vs non-surgical debridement for the treatment of chronic periodontitis," Journal of Clinical Periodontology, vol. 29, supplement 3, pp. 92-102, 2002.

[3] L. Shue, Z. Yufeng, and U. Mony, "Biomaterials for periodontal regeneration: a review of ceramics and polymers," Biomatter, vol. 2, no. 4, pp. 271-277, 2012.

[4] T. Karring, S. Nyman, J. Gottlow, and L. Laurell, "Development of the biological concept of guided tissue regeneration - animal and human studies," Periodontology 2000, vol. 1, no. 1, pp. 26-35, 1993.

[5] M. Retzepi and N. Donos, "Guided bone regeneration: biological principle and therapeutic applications," Clinical Oral Implants Research, vol. 21, no. 6, pp. 567-576, 2010.

[6] R. Langer and J. P. Vacanti, “Tissue engineering," Science, vol. 260, no. 5110, pp. 920-926, 1993.

[7] S. Dabra, K. Chhina, N. Soni, and R. Bhatnagar, "Tissue engineering in periodontal regeneration: a brief review," Dental Research Journal, vol. 9, no. 6, pp. 671-680, 2012.

[8] C. H. F. Hämmerle and W. V. Giannobile, "Biology of soft tissue wound healing and regeneration-consensus report of group 1 of the 10th European workshop on periodontology," Journal of Clinical Periodontology, vol. 41, no. 15, pp. S1-S5, 2014.

[9] A. Sculean, R. Gruber, and D. D. Bosshardt, "Soft tissue wound healing around teeth and dental implants," Journal of Clinical Periodontology, vol. 41, pp. S6-S22, 2014.

[10] F. Vignoletti, J. Nunez, and M. Sanz, "Soft tissue wound healing at teeth, dental implants and the edentulous ridge when using barrier membranes, growth and differentiation factors and soft tissue substitutes," Journal of Clinical Periodontology, vol. 41, supplement 15, pp. S23-S35, 2014.

[11] A. H. Melcher, "On the repair potential of periodontal tissues," Journal of Periodontology, vol. 47, no. 5, pp. 256-260, 1976.

[12] R. M. Meffert, "Guided tissue regeneration/guided bone regeneration: a review of the barrier membranes," Practical periodontics and aesthetic dentistry, vol. 8, no. 2, pp. 142-144, 1996.

[13] S. Nyman, J. Gottlow, J. Lindhe, T. Karring, and J. Wennstrom, "New attachment formation by guided tissue regeneration," Journal of Periodontal Research, vol. 22, no. 3, pp. 252-254, 1987.

[14] S. Nyman, J. Lindhe, T. Karring, and H. Rylander, "New attachment following surgical treatment of human periodontal disease," Journal of Clinical Periodontology, vol. 9, no. 4, pp. 290296, 1982.

[15] S. Kaushal, A. Kumar, M. A. Khan, and N. Lal, "Comparative study of nonabsorbable and absorbable barrier membranes in periodontal osseous defects by guided tissue regeneration," Journal of Oral Biology and Craniofacial Research, vol. 6, no. 2, pp. 111-117, 2016.

[16] A. Sculean, F. Schwarz, J. Becker, and M. Brecx, "The application of an enamel matrix protein derivative $\left(\right.$ Emdogain $\left.^{\circledR}\right)$ in regenerative periodontal therapy: a review," Medical Principles and Practice, vol. 16, no. 3, pp. 167-180, 2007.

[17] M. Esposito, M. G. Grusovin, N. Papanikolaou, P. Coulthard, and H. V. Worthington, "Enamel matrix derivative (Emdogain) for periodontal tissue regeneration in intrabony defects. A Cochrane systematic review," European Journal of Oral Implantology, vol. 2, no. 4, pp. 247-266, 2009.

[18] J. D. Bashutski and H.-L. Wang, "Role of platelet-rich plasma in soft tissue root-coverage procedures: a review," Quintessence International, vol. 39, no. 6, pp. 473-783, 2008.
[19] M. R. Urist and B. S. Strates, "Bone morphogenetic protein," Journal of Dental Research, vol. 50, no. 6, pp. 1392-1406, 1971.

[20] K. Azari, B. A. Doll, C. Sfeir, Y. Mu, and J. O. Hollinger, "Therapeutic potential of bone morphogenetic proteins," Expert Opinion on Investigational Drugs, vol. 10, no. 9, pp. 1677-1686, 2001.

[21] D. Chen, M. Zhao, and G. R. Mundy, "Bone morphogenetic proteins," Growth Factors, vol. 22, no. 4, pp. 233-241, 2004.

[22] S. M. Rao, G. M. Ugale, and S. B. Warad, "Bone morphogenetic proteins: periodontal regeneration," North American Journal of Medical Sciences, vol. 5, no. 3, pp. 161-168, 2013.

[23] P. Kumar, B. Vinitha, and G. Fathima, "Bone grafts in dentistry," Journal of Pharmacy and Bioallied Sciences, vol. 5, no. 5, S1, pp. 125-127, 2013.

[24] E. U. Lee, D. J. Kim, H. C. Lim, J. S. Lee, U. W. Jung, and S. H. Choi, "Comparative evaluation of biphasic calcium phosphate and biphasic calcium phosphate collagen composite on osteoconductive potency in rabbit calvarial defect," Biomaterials Research, vol. 19, no. 1, p. 1, 2015.

[25] X. B. Yang, R. S. Bhatnagar, S. Li, and R. O. C. Oreffo, "Biomimetic collagen scaffolds for human bone cell growth and differentiation," Tissue Engineering, vol. 10, no. 7-8, pp. 11481159, 2004.

[26] E. Sachlos, D. Gotora, and J. T. Czernuszka, "Collagen scaffolds reinforced with biomimetic composite nano-sized carbonatesubstituted hydroxyapatite crystals and shaped by rapid prototyping to contain internal microchannels," Tissue Engineering, vol. 12, no. 9, pp. 2479-2487, 2006.

[27] N. Davidenko, T. Gibb, C. Schuster et al., "Biomimetic collagen scaffolds with anisotropic pore architecture," Acta Biomaterialia, vol. 8, no. 2, pp. 667-676, 2012.

[28] S. S. Lee, B. J. Huang, S. R. Kaltz et al., "Bone regeneration with low dose BMP-2 amplified by biomimetic supramolecular nanofibers within collagen scaffolds," Biomaterials, vol. 34, no. 2, pp. 452-459, 2013.

[29] C. R. Correia, L. S. Moreira-Teixeira, L. Moroni et al., "Chitosan scaffolds containing hyaluronic acid for cartilage tissue engineering," Tissue Engineering Part C: Methods, vol. 17, no. 7, pp. 717-730, 2011.

[30] A. Weyers and R. J. Linhardt, "Neoproteoglycans in tissue engineering," FEBS Journal, vol. 280, no. 10, pp. 2511-2522, 2013.

[31] Y. Lian, L. Yuan, L. Ji, and K. Zhang, "Gelatin/hyaluronic acid nanofibrous scaffolds: biomimetics of extracellular matrix," Acta Biochimica et Biophysica Sinica, vol. 45, no. 8, pp. 700-703, 2013.

[32] C. Credi, S. Biella, C. De Marco, M. Levi, R. Suriano, and S. Turri, "Fine tuning and measurement of mechanical properties of crosslinked hyaluronic acid hydrogels as biomimetic scaffold coating in regenerative medicine," Journal of the Mechanical Behavior of Biomedical Materials, vol. 29, pp. 309-316, 2014.

[33] S. Kim, W.-C. Myung, J.-S. Lee et al., "The effect of fibronectincoated implant on canine osseointegration," Journal of Periodontal and Implant Science, vol. 41, no. 5, pp. 242-247, 2011.

[34] J.-S. Lee, J.-H. Yang, J.-Y. Hong et al., "Early bone healing onto implant surface treated by fibronectin/oxysterol for cell adhesion/osteogenic differentiation: in vivo experimental study in dogs," Journal of Periodontal and Implant Science, vol. 44, no. 5, pp. 242-250, 2014.

[35] Y. Cho, S. Kim, H. Bae et al., "Biomimetic approach to stimulate osteogenesis on titanium implant surfaces using fibronectin derived oligopeptide," Current Pharmaceutical Design, vol. 22, no. 30, pp. 4729-4735, 2016. 
[36] Y.-C. Chang, K.-N. Ho, S.-W. Feng et al., "Fibronectin-grafted titanium dental implants: An in Vivo Study," BioMed Research International, vol. 2016, Article ID 2414809, 11 pages, 2016.

[37] K. E. Park, S. Y. Jung, S. J. Lee, B.-M. Min, and W. H. Park, "Biomimetic nanofibrous scaffolds: preparation and characterization of chitin/silk fibroin blend nanofibers," International Journal of Biological Macromolecules, vol. 38, no. 3-5, pp. 165173, 2006.

[38] I.-S. Yeo, J.-E. Oh, L. Jeong et al., "Collagen-based biomimetic nanofibrous scaffolds: preparation and characterization of collagen/silk fibroin bicomponent nanofibrous structures," Biomacromolecules, vol. 9, no. 4, pp. 1106-1116, 2008.

[39] J. Kundu, Y.-I. Chung, Y. H. Kim, G. Tae, and S. C. Kundu, "Silk fibroin nanoparticles for cellular uptake and control release," International Journal of Pharmaceutics, vol. 388, no. 1-2, pp. 242250, 2010.

[40] J.-P. Chen, S.-H. Chen, and G.-J. Lai, "Preparation and characterization of biomimetic silk fibroin/chitosan composite nanofibers by electrospinning for osteoblasts culture," Nanoscale Research Letters, vol. 7, no. 1, article 170, 2012.

[41] H. Wang, X. Y. Liu, Y. J. Chuah, J. C. H. Goh, J. L. Li, and $\mathrm{H}$. Xu, "Design and engineering of silk fibroin scaffolds with biomimetic hierarchical structures," Chemical Communications, vol. 49, no. 14, pp. 1431-1433, 2013.

[42] B.-X. Zhang, Z.-L. Zhang, A. L. Lin et al., "Silk fibroin scaffolds promote formation of the ex vivo niche for salivary gland epithelial cell growth, matrix formation, and retention of differentiated function," Tissue Engineering-Part A, vol. 21, no. 9-10, pp. 1611-1620, 2015.

[43] D.-H. Shi, D.-Z. Cai, C.-R. Zhou, L.-M. Rong, K. Wang, and Y.-C. Xu, "Development and potential of a biomimetic chitosan/type II collagen scaffold for cartilage tissue engineering," Chinese Medical Journal, vol. 118, no. 17, pp. 1436-1443, 2005.

[44] J. Zhao, W. Han, M. Tu et al., "Preparation and properties of biomimetic porous nanofibrous poly(l-lactide) scaffold with chitosan nanofiber network by a dual thermally induced phase separation technique," Materials Science and Engineering C, vol. 32, no. 6, pp. 1496-1502, 2012.

[45] J. Zhao, W. Han, H. Chen et al., "Fabrication and in vivo osteogenesis of biomimetic poly(propylene carbonate) scaffold with nanofibrous chitosan network in macropores for bone tissue engineering," Journal of Materials Science: Materials in Medicine, vol. 23, no. 2, pp. 517-525, 2012.

[46] D. Algul, H. Sipahi, A. Aydin, F. Kelleci, S. Ozdatli, and F. G. Yener, "Biocompatibility of biomimetic multilayered alginatechitosan/ $\beta$-TCP scaffold for osteochondral tissue," International Journal of Biological Macromolecules, vol. 79, pp. 363-369, 2015.

[47] D. Algul, A. Gokce, A. Onal, E. Servet, A. I. Dogan Ekici, and F. G. Yener, "In vitro release and In vivo biocompatibility studies of biomimetic multilayered alginate-chitosan/ $\beta$-TCP scaffold for osteochondral tissue," Journal of Biomaterials Science, Polymer Edition, vol. 27, no. 5, pp. 431-440, 2016.

[48] R. Junker, A. Dimakis, M. Thoneick, and J. A. Jansen, "Effects of implant surface coatings and composition on bone integration: a systematic review," Clinical Oral Implants Research, vol. 20, supplement 4, pp. 185-206, 2009.

[49] M. Morra, "Biochemical modification of titanium surfaces: peptides and ECM proteins," European Cells and Materials, vol. 12, pp. 1-15, 2006.

[50] J. C. Crockett, M. J. Rogers, F. P. Coxon, L. J. Hocking, and M. H. Helfrich, "Bone remodelling at a glance," Journal of Cell Science, vol. 124, no. 7, pp. 991-998, 2011.
[51] K. Ikeda and S. Takeshita, "Factors and mechanisms involved in the coupling from bone resorption to formation: how osteoclasts talk to osteoblasts," Journal of Bone Metabolism, vol. 21, no. 3, pp. 163-167, 2014.

[52] L. J. Raggatt and N. C. Partridge, "Cellular and molecular mechanisms of bone remodeling," The Journal of Biological Chemistry, vol. 285, no. 33, pp. 25103-25108, 2010.

[53] D. J. Hadjidakis and I. I. Androulakis, "Bone remodeling," Annals of the New York Academy of Sciences, vol. 1092, pp. 385396, 2006.

[54] J. H. Kim and N. Kim, "Regulation of NFATc1 in osteoclast differentiation," Journal of Bone Metabolism, vol. 21, no. 4, pp. 233-241, 2014.

[55] A. F. Mavrogenis, R. Dimitriou, J. Parvizi, and G. C. Babis, "Biology of implant osseointegration," Journal of Musculoskeletal Neuronal Interactions, vol. 9, no. 2, pp. 61-71, 2009.

[56] R. Adell, U. Lekholm, B. Rockler, and P. I. Brånemark, "A 15year study of osseointegrated implants in the treatment of the edentulous jaw," International Journal of Oral Surgery, vol. 10, no. 6, pp. 387-416, 1981.

[57] P.-I. Branemark, "Osseointegration and its experimental background," The Journal of Prosthetic Dentistry, vol. 50, no. 3, pp. 399-410, 1983.

[58] L. Linder, T. Albrektsson, P.-I. Branemark et al., "Electron microscopic analysis of the bone-titanium interface," Acta Orthopaedica, vol. 54, no. 1, pp. 45-52, 1983.

[59] A. Piattelli, A. E. Farias Pontes, M. Degidi, and G. Iezzi, "Histologic studies on osseointegration: soft tissues response to implant surfaces and components. A review," Dental Materials, vol. 27, no. 1, pp. 53-60, 2011.

[60] M. Fini, G. Giavaresi, P. Torricelli et al., "Osteoporosis and biomaterial osteointegration," Biomedicine and Pharmacotherapy, vol. 58, no. 9, pp. 487-493, 2004.

[61] J. E. Davies, "Mechanisms of endosseous integration," International Journal of Prosthodontics, vol. 11, no. 5, pp. 391-401, 1998.

[62] A. P. Ameen, R. D. Short, R. Johns, and G. Schwach, "The surface analysis of implant materials. 1. The surface composition of a titanium dental implant material," Clinical oral implants research, vol. 4, no. 3, pp. 144-150, 1993.

[63] M. McCracken, "Dental implant materials: commercially pure titanium and titanium alloys," Journal of Prosthodontics, vol. 8, no. 1, pp. 40-43, 1999.

[64] M. G. Mesaros, "Osseointegration and the dental endosseous titanium implant interface," The Journal of the Michigan Dental Association, vol. 71, no. 6, pp. 269-275, 1989.

[65] G. A. Zarb and A. Schmitt, "The longitudinal clinical effectiveness of osseointegrated dental implants: the toronto study. Part I: Surgical results," The Journal of Prosthetic Dentistry, vol. 63, no. 4, pp. 451-457, 1990.

[66] D.-H. Li, B.-L. Liu, J.-C. Zou, and K.-W. Xu, "Improvement of osseointegration of titanium dental implants by a modified sandblasting surface treatment: an in vivo interfacial biomechanics study," Implant Dentistry, vol. 8, no. 3, pp. 289-294, 1999.

[67] R. Celletti, V. C. Marinho, T. Traini et al., "Bone contact around osseointegrated implants: a histologic study of acid-etched and machined surfaces," Journal of Long-Term Effects of Medical Implants, vol. 16, no. 2, pp. 131-143, 2006.

[68] M. Degidi, G. Petrone, G. Iezzi, and A. Piattelli, "Bone contact around acid-etched implants: a histological and histomorphometrical evaluation of two human-retrieved implants," Journal of Oral Implantology, vol. 29, no. 1, pp. 13-18, 2003. 
[69] Y.-T. Sul, C. B. Johansson, S. Petronis et al., "Characteristics of the surface oxides on turned and electrochemically oxidized pure titanium implants up to dielectric breakdown: the oxide thickness, micropore configurations, surface roughness, crystal structure and chemical composition," Biomaterials, vol. 23, no. 2, pp. 491-501, 2002.

[70] Y.-T. Sul, “The significance of the surface properties of oxidized titanium to the bone response: special emphasis on potential biochemical bonding of oxidized titanium implant," Biomaterials, vol. 24, no. 22, pp. 3893-3907, 2003.

[71] R. S. Faeda, H. S. Tavares, R. Sartori, A. C. Guastaldi, and E. Marcantonio Jr., "Evaluation of titanium implants with surface modification by laser beam. Biomechanical study in rabbit tibias," Brazilian Oral Research, vol. 23, no. 2, pp. 137-143, 2009.

[72] C.-Y. Park, S.-G. Kim, M.-D. Kim, T.-G. Eom, J.-H. Yoon, and S.G. Ahn, "Surface properties of endosseous dental implants after NdYAG and $\mathrm{CO}_{2}$ laser treatment at various energies," Journal of Oral and Maxillofacial Surgery, vol. 63, no. 10, pp. 1522-1527, 2005.

[73] T. Albrektsson, "Hydroxyapatite-coated implants: a case against their use," Journal of Oral and Maxillofacial Surgery, vol. 56, no. 11, pp. 1312-1326, 1998.

[74] C. Ergun, H. Liu, J. W. Halloran, and T. J. Webster, "Increased osteoblast adhesion on nanograined hydroxyapatite and tricalcium phosphate containing calcium titanate," Journal of Biomedical Materials Research-Part A, vol. 80, no. 4, pp. 990997, 2007.

[75] H. Schliephake, A. Aref, D. Scharnweber, S. Bierbaum, S. Roessler, and A. Sewing, "Effect of immobilized bone morphogenic protein 2 coating of titanium implants on periimplant bone formation," Clinical Oral Implants Research, vol. 16, no. 5, pp. 563-569, 2005.

[76] C. Cassinelli, M. Morra, G. Bruzzone et al., "Surface chemistry effects of topographic modification of titanium dental implant surfaces: 2. In vitro experiments," International Journal of Oral and Maxillofacial Implants, vol. 18, no. 1, pp. 46-52, 2003.

[77] M. Morra, C. Cassinelli, G. Bruzzone et al., "Surface chemistry effects of topographic modification of titanium dental implant surfaces: 1. Surface analysis," International Journal of Oral and Maxillofacial Implants, vol. 18, no. 1, pp. 40-45, 2003.

[78] Z. Qu, X. Rausch-Fan, M. Wieland, M. Matejka, and A. Schedle, "The initial attachment and subsequent behavior regulation of osteoblasts by dental implant surface modification," Journal of Biomedical Materials Research A, vol. 82, no. 3, pp. 658-668, 2007.

[79] I.-S. Yeo, "Reality of dental implant surface modification: a short literature review," Open Biomedical Engineering Journal, vol. 8, no. 1, pp. 114-119, 2014.

[80] D. L. Cochran, "A comparison of endosseous dental implant surfaces," Journal of Periodontology, vol. 70, no. 12, pp. 15231539, 1999.

[81] M. R. Urist, B. F. Silverman, K. Büring, F. L. Dubuc, and J. M. Rosenberg, "The bone induction principle," Clinical Orthopaedics and Related Research, vol. 53, pp. 243-283, 1967.

[82] T.-I. Kim, J.-H. Jang, H.-W. Kim, J. C. Knowles, and Y. Ku, "Biomimetic approach to dental implants," Current Pharmaceutical Design, vol. 14, no. 22, pp. 2201-2211, 2008.

[83] J. F. V. Vincent, O. A. Bogatyreva, N. R. Bogatyrev, A. Bowyer, and A.-K. Pahl, "Biomimetics: its practice and theory," Journal of the Royal Society Interface, vol. 3, no. 9, pp. 471-482, 2006.
[84] S. N. Kaushik, B. Kim, A. M. Walma et al., "Biomimetic microenvironments for regenerative endodontics," Biomaterials Research, vol. 20, article no. 14, 2016.

[85] S. Hinderer, S. L. Layland, and K. Schenke-Layland, "ECM and ECM-like materials-biomaterials for applications in regenerative medicine and cancer therapy," Advanced Drug Delivery Reviews, vol. 97, pp. 260-269, 2016.

[86] K. Gupta, A. Haider, Y. Choi, and I. Kang, "Nanofibrous scaffolds in biomedical applications," Biomaterials Research, vol. 18, article 5, 2014.

[87] R. P. Mecham, "Overview of extracellular matrix," in Current Protocols in Cell Biology, chapter 10, Unit 10.11, 2001.

[88] C. Frantz, K. M. Stewart, and V. M. Weaver, "The extracellular matrix at a glance," Journal of Cell Science, vol. 123, no. 24, pp. 4195-4200, 2010.

[89] R. P. Mecham, "Overview of extracellular matrix," in Current Protocols in Cell Biology, chapter 10, Unit 10. 11, 2012.

[90] R. Pankov and K. M. Yamada, "Fibronectin at a glance," Journal of Cell Science, vol. 115, no. 20, pp. 3861-3863, 2002.

[91] D. A. Puleo and R. Bizios, "Mechanisms of fibronectinmediated attachment of osteoblasts to substrates in vitro," Bone and Mineral, vol. 18, no. 3, pp. 215-226, 1992.

[92] P. Yilgor Huri, G. Huri, U. Yasar et al., "A biomimetic growth factor delivery strategy for enhanced regeneration of iliac crest defects," Biomedical Materials, vol. 8, no. 4, Article ID 045009, 2013.

[93] H.-W. Kim, H.-E. Kim, and V. Salih, "Stimulation of osteoblast responses to biomimetic nanocomposites of gelatin-hydroxyapatite for tissue engineering scaffolds," Biomaterials, vol. 26, no. 25, pp. 5221-5230, 2005.

[94] R. Bernhardt, J. van den Dolder, S. Bierbaum et al., "Osteoconductive modifications of Ti-implants in a goat defect model: characterization of bone growth with SR $\mu \mathrm{CT}$ and histology," Biomaterials, vol. 26, no. 16, pp. 3009-3019, 2005.

[95] L. T. de Jonge, S. C. G. Leeuwenburgh, J. G. C. Wolke, and J. A. Jansen, "Organic-inorganic surface modifications for titanium implant surfaces," Pharmaceutical Research, vol. 25, no. 10, pp. 2357-2369, 2008.

[96] S. Rammelt, C. Heck, R. Bernhardt et al., "In vivo effects of coating loaded and unloaded Ti implants with collagen, chondroitin sulfate, and hydroxyapatite in the sheep tibia," Journal of Orthopaedic Research, vol. 25, no. 8, pp. 1052-1061, 2007.

[97] S. V. Murphy and A. Atala, "3D bioprinting of tissues and organs," Nature Biotechnology, vol. 32, no. 8, pp. 773-785, 2014.

[98] G. Rasperini, S. P. Pilipchuk, C. L. Flanagan et al., "3D-printed bioresorbable scaffold for periodontal repair," Journal of Dental Research, vol. 94, no. 9, supplement, pp. 153S-157S, 2015.

[99] C. H. Park, H. F. Rios, Q. Jin et al., "Tissue engineering boneligament complexes using fiber-guiding scaffolds," Biomaterials, vol. 33, no. 1, pp. 137-145, 2012.

[100] D. A. Zopf, S. J. Hollister, M. E. Nelson, R. G. Ohye, and G. E. Green, "Bioresorbable airway splint created with a threedimensional printer," New England Journal of Medicine, vol. 368, no. 21, pp. 2043-2045, 2013.

[101] J. W. Choi and N. Kim, "Clinical application of threedimensional printing technology in craniofacial plastic surgery," Archives of Plastic Surgery, vol. 42, no. 3, pp. 267-277, 2015.

[102] C. Lee Ventola, "Medical applications for 3D printing: current and projected uses," P \& T, vol. 39, no. 10, pp. 704-711, 2014. 

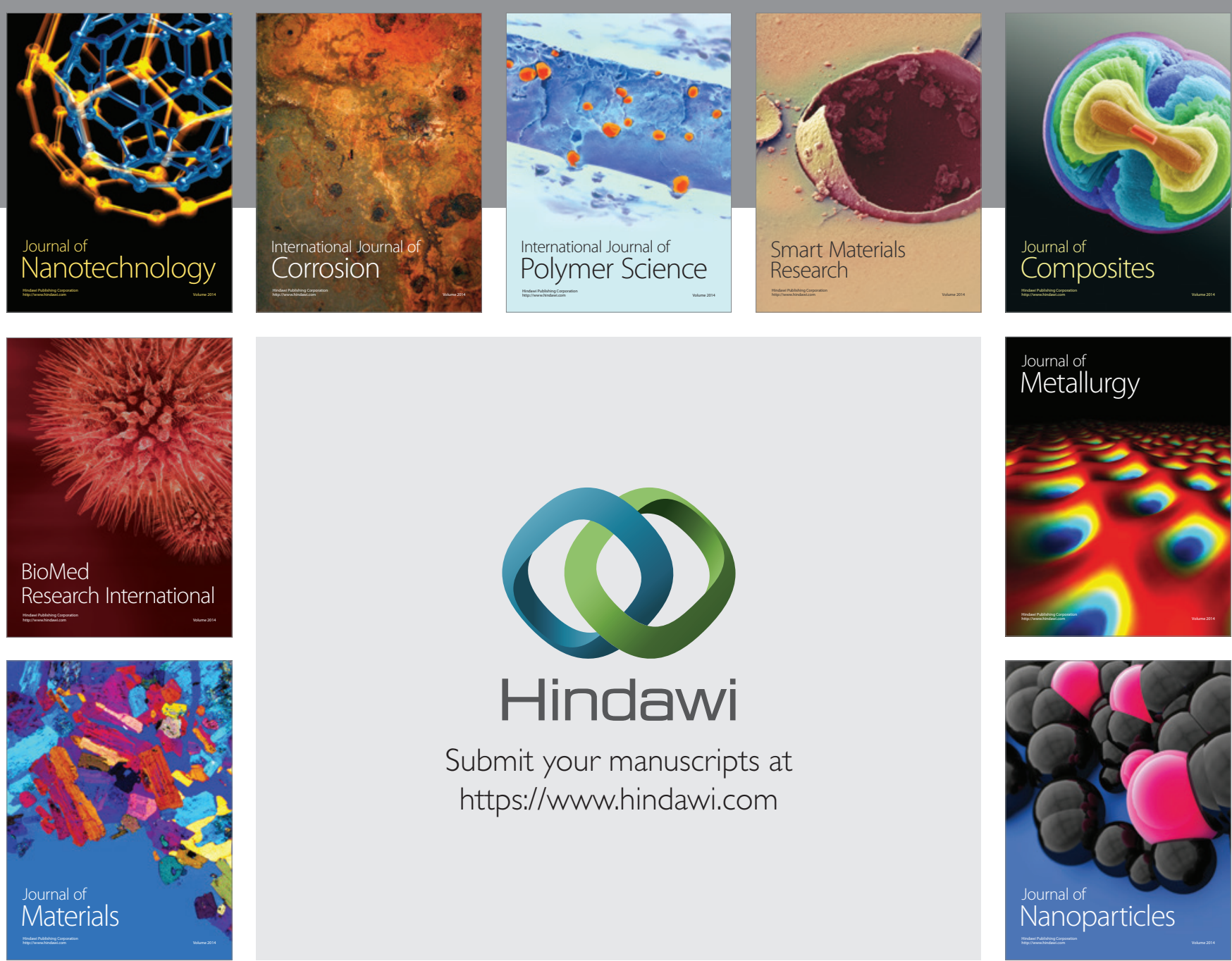

\section{Hindawi}

Submit your manuscripts at

https://www.hindawi.com

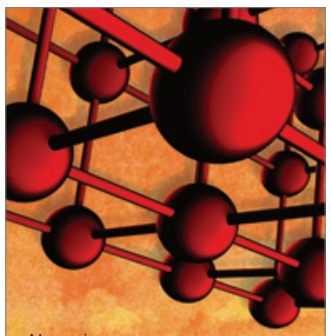

Materials Science and Engineering
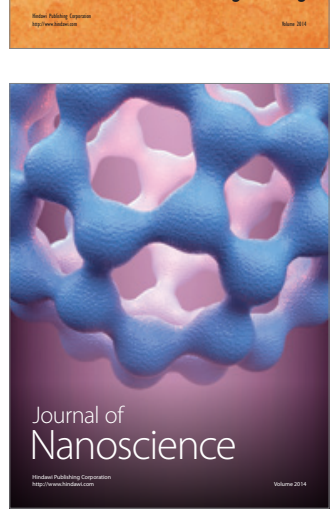
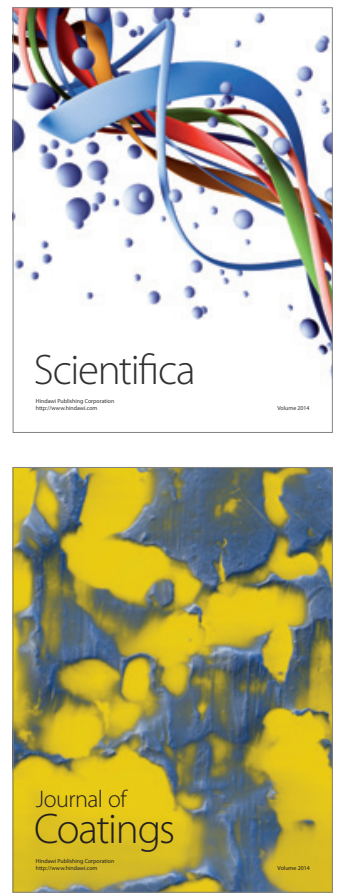
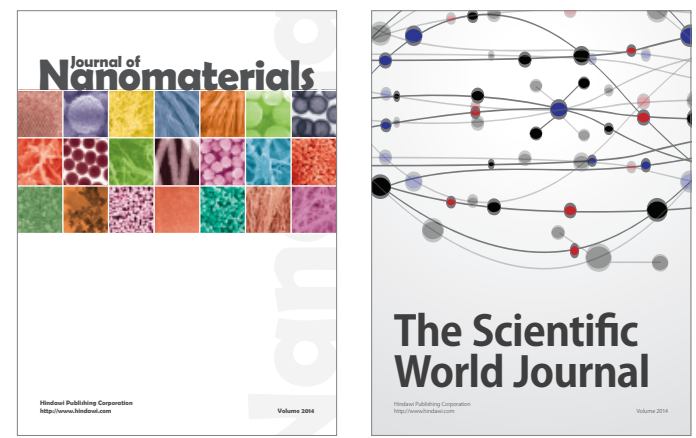

The Scientific World Journal
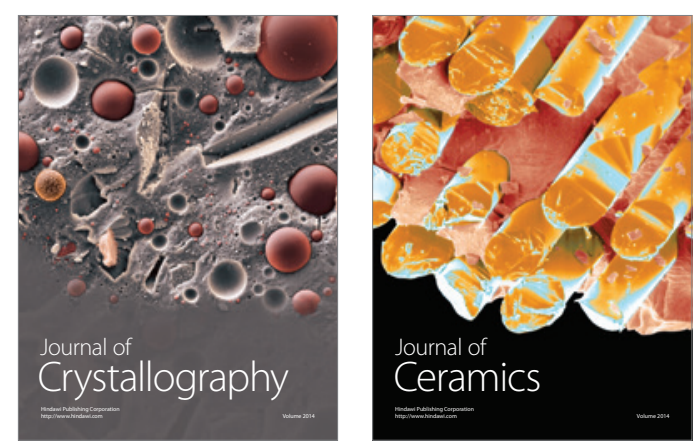
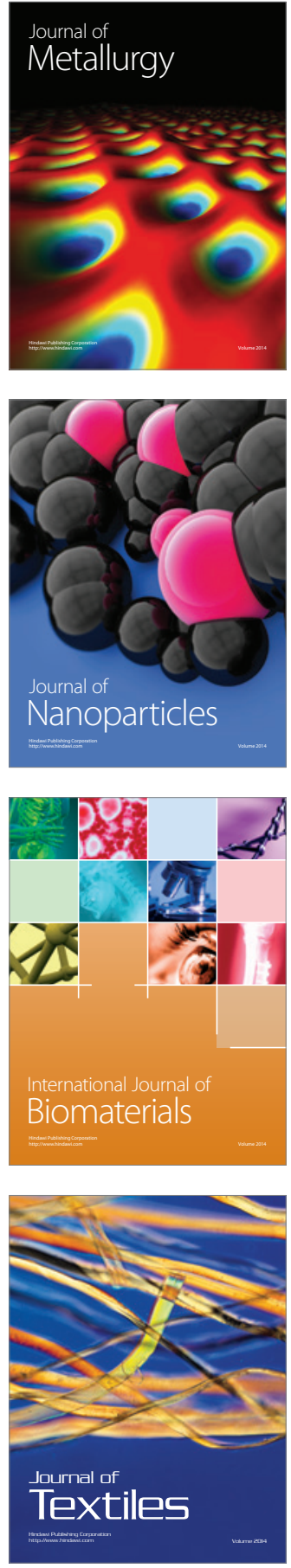